\title{
KARAKTERISTIK PEMBUNGAAN TIGA PROVENAN DAN EMPAT RAS LAHAN CENDANA
}

\author{
Flowering Characteristic of Three Provenances and Four Land Races of Sandalwood \\ Fajar Lestari \\ Balai Penelitian Kehutanan Banjarbaru \\ Jl. A. Yani Km 28,7 Guntung Payung, Landasan Ulin, Banjarbaru, Kalimantan Selatan 70721 \\ Telp./Fax. (0511) 4707872
}

Naskah masuk : 2 Novemver 2009 ; Naskah diterima : 15 Februari 2010

\begin{abstract}
Sandalwood in Wanagama research forest comes from three provenances and four land races that have been able to adapt and reproduce. Even so, this plant has low ability to adapt and reproduce. This research aimed to detect flowering characteristics of sandalwood which is capable of providing information about the stages of flowering characteristics to help towards providing good quality seeds. Purposive sampling method has been used in order to select the sandalwood tree in blossom. Flowering variations of sandalwood consist of each stage of development in a period of flowering, peak flowering, and the characteristics of reproductive organs. The results showed that each provenances and land races have a peak flowering phase which differs in one flowering period. Bromo Mountain Land Race is the fastest on peak flowering phase which happened on second week of January. The time of peak flowering is slowest which acquired on second week of February by Land Races Wanagama, Imogiri, and Bu'at Provenance.
\end{abstract}

\section{Keywords : flowering, provenance, land races, sandalwood}

\begin{abstract}
ABSTRAK
Hutan penelitian Wanagama terdiri atas berbagai jenis tanaman termasuk cendana. Cendana tersebut berasal dari tiga provenan dan empat ras lahan yang telah mampu beradaptasi dan bereproduksi. Namun demikian kemampuan beradaptasi dan bereproduksi tanaman tersebut tergolong rendah. Penelitian ini bertujuan untuk menditeksi karakteristik pembungaan cendana yang diharapkan mampu memberikan informasi mengenai tahap-tahap terjadinya dan karakteristik pembungaan cendana untuk membantu upaya penyediaan benih yang berkualitas. Metode yang digunakan yakni purposive sampling dalam pemilihan pohon cendana yang berbunga. Variasi pembungaan pada cendana meliputi waktu terjadinya tiap tahap perkembangan dalam satu periode pembungaan, puncak pembungaan, karakteristik organ reproduksi. Dari hasil penelitian diperoleh bahwa tiap provenan dan ras lahan mempunyai fase dan puncak pembungaan yang berbeda dalam satu periode pembungaan. Ras Lahan Pegunungan Bromo mengalami puncak pembungaan tercepat yang terjadi pada bulan Januari minggu kedua. Puncak pembungaan paling lambat terjadi di bulan Februari minggu kedua oleh Ras Lahan Wanagama dan Imogiri serta provenan Bu'at.
\end{abstract}

\section{Kata kunci : pembungaan, provenan, ras lahan, cendana}

\section{PENDAHULUAN}

Cendana (Santalum album LINN.) mempunyai keistimewaan dibandingkan dengan jenis-jenis kayu lain. Keistimewaan tersebut dipengaruhi oleh warna, tekstur yang khusus (spesifik), kandungan minyak atsiri dan aroma khas kayu terasnya. Hal tersebut menjadikan cendana mempunyai nilai jual yang cukup tinggi dan menempatkannya sebagai komoditi potensial 
bagi perekonomian Provinsi Nusa Tenggara Timur (NTT). Penyebaran cendana di Indonesia meliputi pulau-pulau Timor, Sumba, Alor, Solor, Pantar, Flores, Roti dan pulau lainnya.

Populasi cendana dengan kepadatan yang cukup tinggi dapat dijumpai di Pulau Timor. Namun saat ini populasinya mulai mengalami penurunan akibat pemanenan yang berlebihan. Hal ini ditunjukkan oleh penurunan jumlah pohon induk sebesar 53,95\% di Pulau Timur dan $88,34 \%$ di Pulau Sumba. Penurunan ini juga disebabkan oleh rendahnya regenerasi dan tingkat keberhasilan penanaman cendana (Haryjanto dkk., 2004). Pada tahun 1993, cendana diintroduksi di Wanagama dan mampu beradaptasi dan beregenerasi secara alami di seluruh kawasan, tetapi tingkat keberhasilannya sangat rendah (Kharisma, 1994).

Penyelamatan populasi cendana telah dilakukan dengan berbagai upaya seperti konservasi, hibridisasi dan rehabilitasi. Kegiatan rehabilitasi yang dilakukan meliputi penanaman secara vegetatif dan generatif atau permudaan alami. Untuk rehabilitasi dengan permudaan alami pada program pemuliaan pohon dibutuhkan informasi awal tentang biologi reproduksi dari suatu jenis tanaman, yang meliputi biologi pembungaan, fenologi pembungaan dan pembuahan serta sistem pembiakan (Ibrahim dan Awang, 1991; Owens et al., 1991). Hasil studi fenologi akan menghasilkan informasi tahap-tahap yang penting dalam perkembangan organ generatif beserta waktu terjadinya dan lama masing-masing tahap tersebut, yang dihubungkan dengan kondisi lingkungan sebagai faktor luar yang mempengaruhinya (Owens et al., 1991). Hal ini terkait dengan tingkat kemasakan buah suatu tanaman (Rathcke, 1983; Bronstein et al., 1990 dalam Inouye et al., 2003). Tingkat kemasakan berkorelasi dengan kualitas benih yang dihasilkan.

Pada lokasi uji ini, cendana yang ditanam berasal dari daerah asal (provenan) dan ras lahan yang berbeda, maka sangat dimungkinkan pembungaannya juga bervariasi. Oleh karena itu perlu dilakukan penelitian karakteristik pembungaan cendana. Tujuan penelitian ini adalah untuk mendeteksi karakteristik pembungaan cendana yang berasal dari provenan dan ras lahan berbeda yang diharapkan mampu memberikan informasi mengenai tahap-tahap terjadinya fenologi pembungaan dan karakteristik pembungaan cendana sehingga membantu upaya penyediaan benih yang berkualitas.

\section{METODOLOGI PENELITIAN}

\section{A. Lokasi Penelitian}

Penelitian dilakukan di lokasi uji provenan cendana tahun tanam 1993, Petak 17, Wanagama I, RPH Gading, BKPH Playen, Gunung Kidul, Yogyakarta. Lokasi penelitian terletak pada ketinggian $200 \mathrm{~m}$ dpl. Daerah ini mempunyai curah hujan rata-rata $2.196,9 \mathrm{~mm} / \mathrm{th}$, dengan bulan kering 2 - 7 bln/th dan bulan basah 4 - 10 bln/th, menurut Schmidt dan Ferguson termasuk iklim D dan E. Topografi sedang-berat, tanah berwarna kecoklatan dengan kedalaman $0-30 \mathrm{~cm}$ (Soeseno dkk., 1988).

\section{B. Asal Pohon Penelitian}

Pohon contoh yang diamati berumur 12 tahun yang berasal dari tiga provenan yaitu Bu'at (Timor Tengah Selatan, NTT), Netpala (Timor Tengah Selatan, NTT), Tilomar (Timor-Timur), dan empat ras lahan yaitu Pegunungan Bromo (Jawa Tengah), Imogiri (Bantul), Wanagama (D.I. Yogyakarta), dan Karang Mojo (Gunung Kidul).

\section{Pengamatan Pembungaan}

Sampel pohon contoh sebanyak 3 pohon untuk pengamatan karakteristik pembungaan Cendana. Pengamatan karakteristik meliputi tahapan perkembangan dan waktu serta tahapan pembungaan berdasarkan tabel waktu terjadinya tahapan pembungaan cendana (Prasetyaningtyas, 2005). Pengamatan dan pengukuran bunga dilakukan dengan mengambil masing-masing satu malai dari ranting pohon sampel. Parameter yang diukur antara lain jumlah bunga, panjang putik dan tangkai sari, serta panjang dan lebar perigonium.

\section{Waktu Pengamatan}

Pengamatan pembungaan dilakukan selama musim berbunga bulan Desember - April. Waktu pengamatan dimulai pagi dan siang hari. Pengamatan dilakukan pada waktu tersebut karena agen-agen penyerbuk banyak melakukan aktivitasnya pada waktu pagi sampai siang hari. Pengamatan dilakukan antara pukul 09.00 - 13.00. 


\section{E. Sampling dan Analisis Data}

Pohon contoh ditentukan secara purposive yakni mewakili seluruh provenan dan ras lahan (Simon, 1996). Karakteristik pembungaan dijelaskan secara deskriptif dilengkapi dengan grafik tahapan perkembangan dan waktu berlangsungnya tahap pembungan.

\section{HASIL DAN PEMBAHASAN}

\section{A. Waktu Terjadinya Tahap Pembungaan}

Hasil pengamatan menunjukkan terdapat perbedaan waktu terjadinya tahapan pembungaan antar provenan dan ras lahan. Waktu terjadinya tahapan pembungaan masing-masing provenan dan ras lahan disajikan pada Tabel 1.

Tabel(Table) 1. Waktu terjadinya tahap pembungaan cendana dari berbagai provenan dan ras lahan (Flowering period of sandalwood of each provenance and land race)

\begin{tabular}{|c|c|c|c|c|c|c|c|c|c|c|c|c|c|c|c|c|c|c|c|c|}
\hline \multirow{3}{*}{$\begin{array}{l}\text { Provenan dan } \\
\text { ras lahan } \\
\text { (Provenance and } \\
\text { land race) }\end{array}$} & \multicolumn{20}{|c|}{ Waktu perkembangan bunga (minggu) / Flowering period (week) } \\
\hline & \multicolumn{4}{|c|}{$\begin{array}{l}\text { Desember/minggu } \\
\text { (December/week) }\end{array}$} & \multicolumn{4}{|c|}{$\begin{array}{l}\text { Januari/minggu } \\
\text { (January/week) }\end{array}$} & \multicolumn{4}{|c|}{$\begin{array}{l}\begin{array}{l}\text { Februari/minggu } \\
\text { (February/week) }\end{array} \\
\end{array}$} & \multicolumn{4}{|c|}{$\begin{array}{l}\text { Maret/minggu } \\
\text { (March/week) }\end{array}$} & \multicolumn{4}{|c|}{$\begin{array}{l}\text { April/minggu } \\
\text { (April/week) }\end{array}$} \\
\hline & I & II & III & IV & I & II & III & IV & I & II & III & IV & I & II & III & IV & I & II & III & IV \\
\hline Bu'at & & & & & & & & & & & & & & & & & & & & \\
\hline Tilomar & & & & & & & & & & & & & & & & & & & & \\
\hline Wanagama & & & & & & & & & & & & & & & & & & & & \\
\hline Imogiri & & & & & & & & & & & & & & & & & & & & \\
\hline Karang Mojo & & & & & & & & & & & & & & & & & & & & \\
\hline Netpala & & & & & & & & & & & & & & & & & & & & \\
\hline Peg. Bromo & & & & & & & & & & & & & & & & & & & & \\
\hline
\end{tabular}

Keterangan (Remarks):

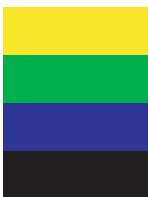

: tahap pembentukan tunas produktif

: tahap perkembangan kuncup awal

: tahap perkembangan kuncup maksimal

: tahap perkembangan bunga anthesis

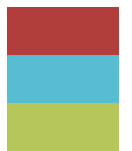

tahap perkembangan bunga reseptif : tahap perkembangan buah muda : tahap perkembangan buah tua
Berdasarkan Tabel 1, waktu terjadinya permulaan pembungaan cendana bervariasi antar provenan dan ras lahan. Pembentukan awal bunga tidak terjadi secara bersamaan di seluruh pohon, sehingga buah yang terbentuk dan waktu kemasakannya juga berbeda. Inisiasi tunas produktif untuk provenan Bu'at, ras lahan Karang Mojo dan ras lahan Pegunungan Bromo terjadi pada bulan Desember. Inisiasi tersebut lebih cepat dibandingkan dengan ras lahan dan provenan lain. Hal ini menyebabkan ras lahan tersebut mengalami fase buah menuju kemasakan lebih cepat kecuali pada ras lahan Pegunungan Bromo yang terjadi pada bulan Maret. Ras Lahan Pegunungan Bromo mengalami inisiasi tunas produktif lebih cepat, tetapi pada fase kemasakan buah paling lambat.

Fenomena ini terjadi karena tidak semua bunga berhasil membentuk buah, terkait dengan adanya faktor endogen dan kondisi lingkungan. Faktor endogen antara lain: adanya kompetisi serbuksari yang terjadi antar bunga dalam satu malai dan dalam satu pohon, perbedaan waktu kematangan putik dan benangsari. Hal ini dikarenakan bunga cendana termasuk ke dalam tipe protandri dichogami, yaitu tipe bunga dengan waktu kemasakan organ reproduksi terjadi secara tidak bersamaan. Organ reproduksi jantan atau benangsari masak terlebih dahulu dibandingkan dengan organ reproduksi betina atau putik (Ratnaningrum dan Prehaten, 2005). Prasetyaningtyas (2005) menyatakan banwa gugurnya buah muda menuju kemasakan pada cendana (open pollination) berkisar 17,4\%. Sedangkan Owen dan Blake (1985) dalam Owen et al. (1991) menyebutkan terdapat empat hal yang menyebabkan tingginya tingkat keguguran atau kerusakan ovul yaitu: (1) rendahnya kualitas tepung sari, (2) prezigotic self incompability, (3) kegagalan penyerbukan dan (4) kompetisi cadangan makanan.

Faktor lingkungan yang mempengaruhi keberhasilan pembentukan buah dari bunga berupa cuaca atau keadaan pada saat 
pengamatan. Pengamatan ini dilakukan pada musim penghujan sehingga banyak buah-buah muda yang mengalami kerontokan dan gugur sebelum masak. Air hujan menyebabkan kuncup bunga membusuk sebelum mekar. Selain itu perbedaan fase pembungaan juga disebabkan oleh ketersediaan dan pemulihan energi serta sumber lain yang digunakan dalam proses pembungaan (Tyler, 2001).

Faktor lingkungan berkorelasi dengan tahap-tahap perkembangan dalam siklus hidup suatu tanaman. Larcher (1995) menyatakan bahwa fenologi suatu tanaman merupakan indikator dari karakteristik iklim serta perubahan musim. Sedangkan menurut Rathcke dan Lacey (1985) faktor lingkungan yang mempengaruhi inisiasi pembungaan adalah temperatur, fotoperiode, dan presipitasi.

\section{B. Karakteristik Organ Repoduksi}

Bunga merupakan organ reproduksi cendana yang terdiri atas putik, benang sari dan perigonium. Organ tersebut merupakan komponen penting yang mempengaruhi keberhasilan penyerbukan. Kualitas penyerbukan akan mempengaruhi tingkat keberhasilan produksi buah suatu jenis tanaman. Fase pembungaan cendana dalam satu periode pembungaan dimulai dengan pembentukan kuncup awal yang berkembang menjadi kuncup maksimal, masa anthesis, dan terakhir masa reseptif.

Hasil pengamatan karakteristik organ reproduksi terhadap tiga provenan dan empat ras lahan cendana disajikan Tabel 2.

Tabel(Table) 2. Ukuran organ reproduksi cendana dari masing-masing provenan dan ras lahan (Size of reproductive organ of each provenances and land races)

\begin{tabular}{|c|c|c|c|c|c|}
\hline \multirow{2}{*}{$\begin{array}{c}\text { Provenan dan } \\
\text { ras lahan } \\
\text { (Provenance } \\
\text { and land } \\
\text { race) }\end{array}$} & \multirow{2}{*}{$\begin{array}{c}\text { Panjang } \\
\text { tangkai putik } \\
\text { (Length of stylus) } \\
\text { (mm) }\end{array}$} & \multirow{2}{*}{$\begin{array}{c}\text { Panjang } \\
\text { tangkai sari } \\
(\text { Length of } \\
\text { filament })(\mathrm{mm})\end{array}$} & \multicolumn{3}{|c|}{ Perigonium (mm) } \\
\hline & & & $\begin{array}{c}\text { Lebar tabung } \\
\text { perigonium } \\
\text { (width of perigonum's } \\
\text { tube) }\end{array}$ & $\begin{array}{c}\text { Lebar } \\
\text { perigonium } \\
\text { (width of perigonum) }\end{array}$ & $\begin{array}{l}\text { Panjang } \\
\text { (Length) } \\
\text { (mm) }\end{array}$ \\
\hline Bu'at & 1,53 & 1,81 & 1,88 & 5,47 & 3,64 \\
\hline Tilomar & 1,46 & 1,90 & 2,37 & 6,17 & 3,22 \\
\hline Wanagama & 1,52 & 1,89 & 2,06 & 5,39 & 3,32 \\
\hline Imogiri & 1,41 & 1,51 & 2,70 & 5,19 & 3,78 \\
\hline Krg. Mojo & 1,50 & 1,65 & 2,06 & 5,46 & 3,69 \\
\hline Netpala & 1,49 & 1,93 & 3,31 & 5,46 & 3,84 \\
\hline P.Bromo & 1,49 & 1,58 & 2,05 & 4,81 & 3,47 \\
\hline
\end{tabular}

Data pada Tabel 2 menunjukkan adanya variasi ukuran organ reproduksi tiap provenan dan ras lahan. Variasi tersebut ditunjukkan oleh adanya perbedaan ukuran putik, benangsari maupun perigonium, walaupun perbedaan tersebut tidak begitu nyata pada masing-masing provenan dan ras lahan. Perigonium merupakan gabungan antara kelopak dan mahkota karena pada bunga cendana tidak dapat dibedakan dengan jelas. Perbedaan ukuran ini menunjukkan perbedaan karakteristik bunga yang akan mempengaruhi dan menentukan tingkat pengunjung bunga. Faktor ini juga akan mempengaruhi tingkat keberhasilan penyerbukan. Secara alami, ukuran tangkai sari lebih panjang daripada tangkai putik karena berkaitan dengan proses penyerbukan. Haryanto (2005) melaporkan bahwa bunga cendana bervariasi pada karakteristik panjang tangkai putik, panjang bakal buah, panjang benang sari, jumlah bunga/malai, panjang malai, panjang dan lebar.

Kondisi berbeda ditunjukkan oleh bagian asesori bunga seperti ukuran perigonium. Ukuran perigonium tidak berpengaruh nyata dibandingkan dengan warna dari perigonium itu sendiri. Warna ini akan mempengaruhi jumlah penyerbuk atau pengunjung bunga yang datang, oleh karena itu sebagian besar bunga mempunyai warna dan bentuk yang menarik. Warna bunga bisa diartikan sebagai suatu bentuk penyesuaian diri tanaman terhadap lingkungan tempat tumbuhnya (Montellano \& Eguiarte, 2003)

Ukuran struktur bunga akan mempengaruhi tingkat keberhasilan penyerbukan dan 
akan menentukan tingkat keberhasilan pembuahan. Serbuksari merupakan tujuan utama dari pengunjung bunga, dan ukuran bunga akan mempengaruhi jumlah pengunjung bunga. Tiap penyerbuk atau pengunjung bunga dalam satu waktu akan mengunjungi bunga yang berbeda, sehingga aktivitas ini akan menguntungkan bagi penyerbukan pohon-pohon dalam suatu tegakan (Ratnaningrum, 1998).

\section{Periode Puncak Pembungaan}

Puncak pembungaan provenan dan ras lahan cendana dapat dilihat pada Gambar 1.
Puncak pembungaan untuk provenan dan ras lahan cendana tampak berbeda (Gambar 1). Puncak pembungaan tercepat pada ras lahan Pegunungan Bromo yang terjadi pada minggu ke dua bulan Januari, diikuti oleh provenan Bu'at dan ras lahan Karang Mojo pada minggu ke tiga bulan yang sama yaitu bulan Januari. Ras lahan dengan puncak pembungaan lambat yakni provenan Tilomar, ras lahan Wanagama, ras lahan Imogiri dan provenan Netpala yang terjadi pada bulan Februari. Secara umum satu periode pembungaan cendana rata-rata berlangsung selama 107 hari (Prasetyaningtyas, 2005).

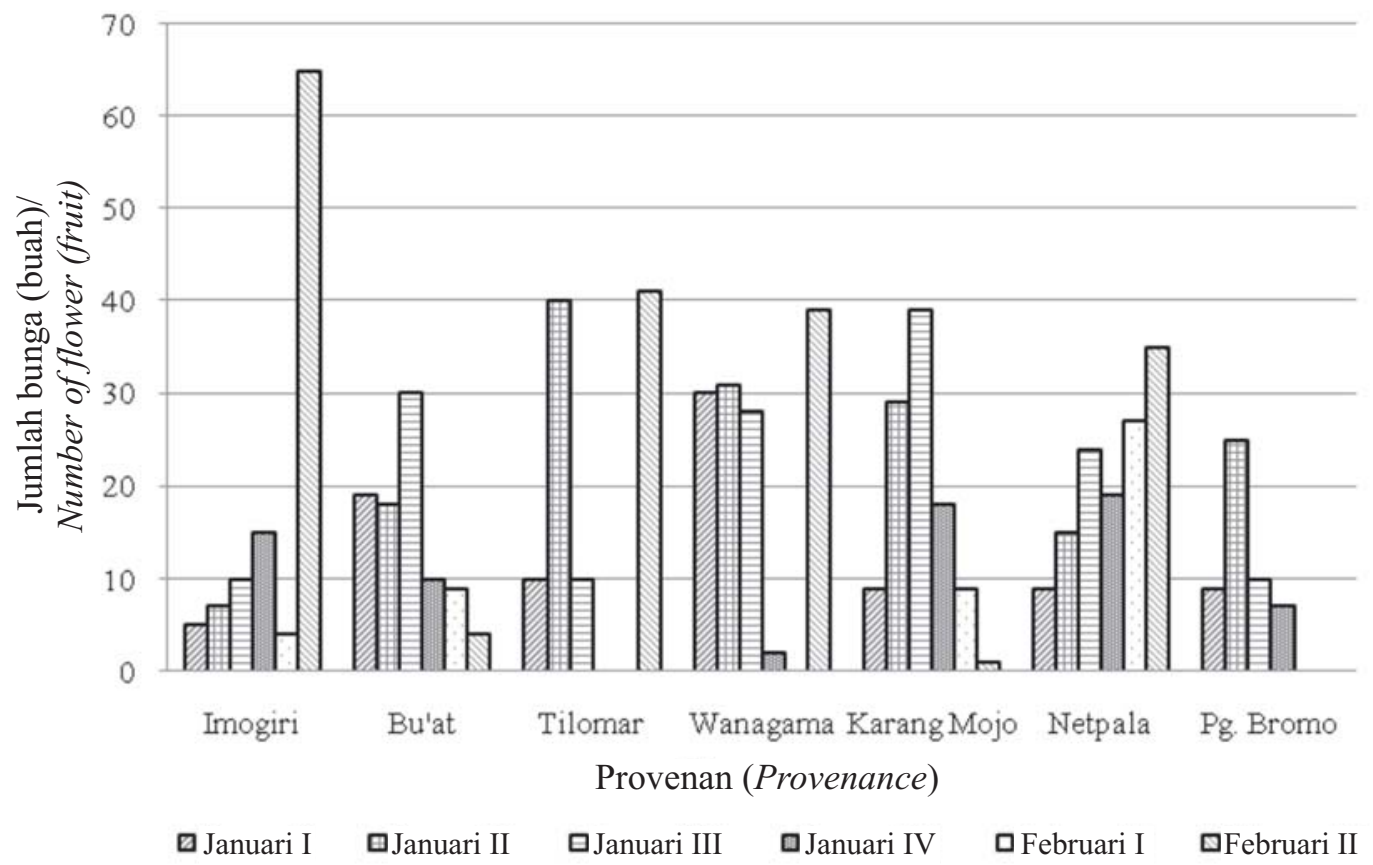

Gambar(Figure) 1. Periode puncak pembungaan cendana (Peak of flowering period of cendana sandalwood)

Perbedaan puncak pembungaan dipengaruhi oleh variasi inisiasi awal bunga dari masingmasing provenan dan ras lahan. Waktu terjadinya permulaan pembungaan sangat bervariasi baik antar provenan, antar tegakan maupun antar individu dalam tegakan. Variasi ini juga dapat dijumpai antar periode dan tempat yang berbeda (Prasetyaningtyas, 2005). Waktu yang diperlukan tanaman untuk mulai berbunga bervariasi dan tidak hanya tergantung pada umur saja, tetapi juga oleh interaksi antara faktor endogen dan kondisi lingkungan(Gardner et al., 1991).

Puncak pembungaan cendana terjadi pada saat bunga mengalami fase anthesis. Setelah fase anthesis organ-organ reproduksi memasuki fase reseptif yaitu fase pada saat bunga siap melakukan penyerbukan. Terdapat beberapa faktor yang mempengaruhi keberhasilan penyerbukan salah satunya adalah kematangan organ reproduksi.

Kematangan organ reproduksi bunga cendana meliputi kematangan tepung sari dan kepala putik. Kematangan tepung sari dapat dideteksi melalui perubahan warna anthera dari kuning terang menjadi orange tua atau jingga, sedangkan reseptivitas putik dapat diketahui dari perubahan ukuran dan warna stigma yang semula berwarna kuning terang, merah cerah kemudian 
berubah menjadi merah marun. Kematangan pollen terjadi beberapa saat sebelum bunga memasuki fase anthesis, dan reseptivitas kepala putik terjadi 3 - 7 hari setelah bunga memasuki fase anthesis (Prasetyaningtyas, 2005).

Warna dari organ reproduksi dapat menjadi indikasi fase pembungaan. Warna perigonium sebelum anthesis dan setelah anthesis bunga cendana adalah sama yaitu kuning terang untuk perigonium bagian luar, dan jingga untuk perigonium bagian dalam. Setelah anthesis warna perigonium berubah menjadi merah sampai dengan merah marun, baik bagian dalam maupun luar. Bentuk perigonium dan warna serbuksari provenan dan ras lahan bunga cendana adalah sama. Bentuk perigonium cendana bagian dalam adalah oval dan bagian luar adalah lanset. Pohon yang berbunga asal Tilomar menunjukkan fenomena yang sedikit berbeda dibanding lainnya. Pada fase reseptif bunganya tidak sampai berwarna merah marun, tetapi mempunyai ukuran perigonium paling panjang dan sempit. Karakteristik ini menunjukkan bahwa perbedaan morfologi bunga dan ukuran organ reproduksi lebih dipengaruhi oleh faktor genetik dari tanaman itu sendiri.

\section{KESIMPULAN}

Fase pembungaan tiga provenan dan empat ras lahan cendana yaitu ras lahan Pegunungan Bromo, provenan Bu'at, ras lahan Karang Mojo, provenan Tilomar, ras lahan Wanagama I, ras lahan Imogiri dan provenan Netpala terjadi pada waktu yang berbeda dalam satu periode pembungaan. Waktu peak flowering season (puncak pembungaan) cendana dicapai bulan Januari untuk ras lahan Pegunungan Bromo, provenan Bu'at, ras lahan Karang Mojo dan bulan Februari provenan Tilomar, ras lahan Wanagama, ras lahan Imogiri dan provenan Netpala. Hasil penelitian ini dapat dijadikan sebagai acuan waktu pengunduhan yang tepat dalam rangka penyediaan benih yang berkualitas.

\section{UCAPAN TERIMAKASIH}

Penulis mengucapkan terimakasih kepada Dr. Bambang Sunarko atas bimbangan dan masukannya dalam penyusunan karya tulis ilmiah ini. Penulis mengucapkan terimakasih kepada Fakultas Kehutanan UGM yang telah memfasilitasi kegiatan penelitian ini. Penulis juga mengucapkan terima kasih kepada Bambang Setyo Antoko, S.Hut. yang telah memperbaiki abstrak dari tulisan ini.

\section{DAFTAR PUSTAKA}

Gardner, F.P., R.B. Pearce dan R.L. Mitchell. 1991. Fisiologi Tanaman Budidaya (Terjemahan). UI Press, Jakarta.

Haryjanto, L., T. Herawan, Yuliah dan T. Pamungkas. 2004. Upaya Konservasi dan Penyediaan Benih untuk Rehabilitasi Sumber Daya Hutan Cendana (Santalum album Linn) Prosiding Ekspose Hasil Litbang Bioteknologi dan Pemuliaan Pohon Tanaman Hutan, 24 Desember 2003. Yogyakarta

Haryanto, Y. 2005. SKRIPSI. Informasi Awal Kinerja Hasil Penyerbukan Terkendali (Crossing, Selfing, dan Open Pollination) pada Cendana (Santalum album Linn.) Di Wanagama I. Fakultas Kehutanan Universitas Gadjah Mada. Yogyakarta.

Ibrahim, Z dan K. Awang. 1991. Flowering and fruiting phenology of Acacia mangium and Acacia auculiformis in peninsular Malaysia. Aciar Proceeding No. 37.

Inouye, D., W.F. Savedra dan W. Lee-Yang. 2003. Environmental Influences on The Phenology and Abundance of Flowering by Androsace septentrionalis (Primulaceae). American Journal of Botany 90 (6) : 905 - 910.

Kharisma. 1994. TESIS. Kombinasi Uji Keturunan dan Uji Sumber Benih Cendana Tingkat Semai. Program Pasca Sarjana. Universitas Gadjah Mada Yogyakarta. Tidak dipublikasikan.

Larcher, W. 1995. Physiology Plant Ecology. Springer. Verlag berlin Heidelberg. Germany.

Montellano, A.S., and L.E.Eguiarte. 2003. Geographic Pattern in The Reproductive Ecology of Agave lechuguilla (Agaveceae) in the Chihuahuan Desert, 
Floral Characteristics, Visitor and Fecundity. American Journal Of Botany. Mexico

Owens, J.N., Sornsathapornkul. P, dan Thangmitcharoen, S. 1991. Studying Flowering and Seed Ontogeny in Tropical Forest Trees. ASEAN-Canada Forest Tree Seed Centre. Muak-lek, Saraburi 18180, Thailand.

Prasetyaningtyas, M. 2005. TESIS. Studi Fenologi Pembungaan dan Penyerbukan Santalum album Linn. Program Pasca Sarjana Universitas Gadjah Mada, Yogyakarta. Tidak Dipublikasikan.

Ratchke, B.J dan E.P. Lacey. 1985. Phenological Pattern of Terrestrial Plants. Annual Review of Ecology and Systematic 16 : 179- 214.

Ratnaningrum, Y.W.N. 1998. SKRIPSI. Studi Fenologis Pembungaan, Penyerbukan dan Pembuahan Eucalyptus pellita F. Moell. Fakultas Kehutanan Universitas Gadjah Mada Yogyakarta. Tidak dipublikasikan.
Ratnaningrum, Y.W.N dan D. Prehaten. 2005. Pollination Mechanism and Breeding System of Santalum album (Santalaceae), The Endemic Species of Eastern Part of Indonesia that became Landrace of Gunung Kidul, Central Java. Prosiding Internasional Seminar. University Putra Malaysia.

Simon, H. 1996. Metoda Inventore Hutan. Aditya Media. Yogyakarta.

Soeseno, O.H., Tri, S., Sukirno, D.P., Anwar, B., Sri, D., Soedjoko, D.S., Winastuti, W.W. Winarni., Anwar, Ch. dan Suginingsih. 1988. Master Plan Wanagama I Sebagai Sarana Penunjang HTI. Kerjasama Fakultas Kehutanan Universitas Gadjah Mada dan Departemen Kehutanan.

Tyler, G. 2001. Relationship between climate and flowering of eight herbs in a Swedish deciduous forest. Annals of Botany 87 : $623-630$ 